Jayalath, C. and Somarathna, K.K.G.P., 2021. Key performance indicators in upholding scope creep management in road projects. In: Sandanayake, Y.G., Gunatilake, S. and Waidyasekara, K.G.A.S. (eds). Proceedings of the $9^{\text {th }}$ World Construction Symposium, 9-10 July 2021, Sri Lanka. [Online]. pp. 381-391. DOI: https://doi.org/10.31705/WCS.2021.33. Available from: https://ciobwcs.com/papers/

\title{
KEY PERFORMANCE INDICATORS IN UPHOLDING SCOPE CREEP MANAGEMENT IN ROAD PROJECTS
}

\author{
Chandana Jayalath $^{1}$ and K.K.G.P Somarathna ${ }^{2}$
}

\begin{abstract}
Scope creep has been a day-to-day occurrence in almost every major road project causing a considerable cost overrun with no early dimple. This paper offers a critical appraisal on the dominant causes behind scope creep in the road projects. A comprehensive literature survey was undertaken to explore the factors specifically contributing scope creep and various control measures that are adopted, among other purposes, in at least reducing the impact due to scope creep in the final delivery of road projects. The study included interviews with 15 experts to identify major issues and add their hands-on experience. A questionnaire survey was subsequently administered among 100 industrial personnel having a cost management background in order to evaluate the effectiveness of the key performance indicators (KPIs) in terms of taming scope creep. Results from the study showed that concomitant client instructions on additional features, unclear scope and incremental changes cause scope creep throughout the project. Among 53 KPIs identified, the most effective KPI that enables adequate control of scope creep in road projects is the cost efficiency ratio. The results enable comprehending the causes of scope creep and its resultant net effect on cost control.
\end{abstract}

Keywords: Cost controlling techniques; Cost overrun; Key Performance Indicators (KPIs); Road projects; Scope creep.

\section{INTRODUCTION}

Cost overruns are inevitable even in projects delivered well (Zwikael, 2009). Nivehithan (2017) revealed that cost overrun can even result in early cessation. Thus, it is necessary to implement cost control mechanisms to ensure no deviations. The study done by Malkanthi et al., (2017) has revealed that cost variance can be reduced as much as $50 \%$ through the use of appropriate cost control techniques. As such, most of the literature has focused on various cost control techniques for general application (Koushki et al., 2005). The effectiveness of a cost controlling technique will depend on the measure of its performance (Neely et al., 2005). Performance measurement is to objectively reckon the efficiency and effectiveness of a given task. It allows making judgments against certain predetermined criteria (Neely et al., 2005; Basheka and Tumutegyereize, 2011). KPIs are therefore essential in terms of finding the current status as well as the 'remaining balance'. Swan and Kyng (2004) contend that monitoring KPIs are critical in any project. Thoor

\footnotetext{
${ }^{1}$ Department of Quantity Surveying, University of Vocational Technology, Sri Lanka, jayalathchandana@gmail.com

${ }^{2}$ University College of Batangala, Sri Lanka, kkgpsomarathna123@gmail.com
} 
and Ogunlana (2010), together with Humaidi and Said (2011), suggested that KPIs are helpful to compare the actual with estimated performance in terms of effectiveness. KPIs are outcomes from an industry-led self-improvement initiative rather than a top-down imposition from government (Kumaraswamy et al., 2017). In 30 mega infrastructure projects in India, road projects are found to have largest amount of time and cost overruns (Narayanan et al., 2019). Among a host of reasons, scope creep, is exceptional in road projects in a way it is silently contributing cost overrun in long run. Most projects seem to sustain scope creep (Larson and Larson, 2009). A few researchers have attempted to gauge the effectiveness of KPI however no research is found in reference to their application in scope creep. Hence, the research problems considered in this paper are 'Is there any particular KPI that effectively works in taming scope creep in road projects?

This research aims to enhance awareness among the construction practitioners to successfully cope with scope creep that take place in road construction projects. The objectives encompassing this study are to, (1) identify the factors contributing scope creep resulting in cost and schedule overrun, (2) identify the various cost management functions and key performance indicators in the sphere of scope creep management, and (3) statistically measure the level of their effectiveness in taming cost overrun in road projects.

\section{FACTORS CONTRIBUTING SCOPE CREEP}

As such, many researchers have identified a gamut of factors that cause scope creep in road projects and the associated KPI and recommended for the adoption during the project execution stage (refer Table 1).

Table 1: Factors contributing to scope creep in road projects \& KPIs

\begin{tabular}{|c|c|c|c|}
\hline \# & Author & $\begin{array}{l}\text { Factors contributing scope creep } \\
\text { in road projects }\end{array}$ & KPI recommended \\
\hline 1 & Arditi et al. (1985) & $\begin{array}{l}\text { Substitution of materials as a result } \\
\text { of resource shortages }\end{array}$ & $\begin{array}{l}\text { Net scope change (add and } \\
\text { omit schedule) }\end{array}$ \\
\hline 2 & $\begin{array}{l}\text { Dlakwa and } \\
\text { Cuplin (1990) }\end{array}$ & $\begin{array}{l}\text { Unstable interest rates, too many } \\
\text { temporary diversions than planned }\end{array}$ & Budgeted cost of work done \\
\hline 3 & $\begin{array}{l}\text { Hendrickson } \\
(1998)\end{array}$ & $\begin{array}{l}\text { Cascading effects due to less } \\
\text { productivity }\end{array}$ & Lead time, productivity ratio \\
\hline 4 & $\begin{array}{l}\text { Larson and Larson } \\
(2009)\end{array}$ & Change in specifications & $\begin{array}{l}\text { Reduced timing, } \\
\text { productivity ration, variation } \\
\text { log }\end{array}$ \\
\hline 5 & $\begin{array}{l}\text { Smith and Love } \\
(2001)\end{array}$ & $\begin{array}{l}\text { Abortive work, lasts minute } \\
\text { adjustments by the end user }\end{array}$ & $\begin{array}{l}\text { Number of Rework } \\
\text { approved }\end{array}$ \\
\hline 6 & $\begin{array}{l}\text { Smith and Love } \\
(2001)\end{array}$ & Incremental design changes & Claims \\
\hline 7 & $\begin{array}{l}\text { Sonuga et al. } \\
(2002)\end{array}$ & $\begin{array}{l}\text { Change in elevations, sections and } \\
\text { plans }\end{array}$ & $\begin{array}{l}\text { Under measure added, } \\
\text { variation log, EI instructions } \\
\text { responded, design changes } \\
\text { authenticated }\end{array}$ \\
\hline 8 & $\begin{array}{l}\text { Aibinu and } \\
\text { Jagboro (2002) }\end{array}$ & $\begin{array}{l}\text { Unexpected incremental price } \\
\text { increases on daily basis }\end{array}$ & Cash flow yield \\
\hline
\end{tabular}




\begin{tabular}{|c|c|c|c|}
\hline$\#$ & Author & $\begin{array}{l}\text { Factors contributing scope creep } \\
\text { in road projects }\end{array}$ & KPI recommended \\
\hline 9 & Gurlen (2003) & Unintended directions & Approved varied work \\
\hline 10 & $\begin{array}{l}\text { Baloi and Price } \\
\text { (2003) }\end{array}$ & $\begin{array}{l}\text { fluctuation of exchange rates, sub } \\
\text { surface works where the theoretical } \\
\text { quantities exceed }\end{array}$ & Cash flow margin \\
\hline 11 & $\begin{array}{l}\text { Baloi and Price } \\
\text { (2003) }\end{array}$ & Continuous design changes & $\begin{array}{l}\text { Variation log, potential } \\
\text { change notices approved, }\end{array}$ \\
\hline 12 & $\begin{array}{l}\text { Koushki and } \\
\text { Kartam (2004) }\end{array}$ & $\begin{array}{l}\text { Change in line, level and alignments, } \\
\text { change in super elevation, change in } \\
\text { specifications as to mix of asphalt, } \\
\text { mix of concrete, type of soil }\end{array}$ & $\begin{array}{l}\text { Site log book signed and } \\
\text { confirmed, variation log }\end{array}$ \\
\hline 13 & $\begin{array}{l}\text { Koushki and } \\
\text { Kartam (2004) }\end{array}$ & Plant idling & Mark up eroded \\
\hline 14 & $\begin{array}{l}\text { Hanna and } \\
\text { Gunduz (2004) }\end{array}$ & Low labour productivity & $\begin{array}{l}\text { Cost benefit ratio, } \\
\text { productivity ratio }\end{array}$ \\
\hline 15 & $\begin{array}{l}\text { Chester and } \\
\text { Hendrickson } \\
(2005)\end{array}$ & $\begin{array}{l}\text { Labour inefficiency, wrong estimate } \\
\text { in quantities }\end{array}$ & $\begin{array}{l}\text { Employer Instruction (EI) } \\
\text { the cost of which is } \\
\text { confirmed in principle }\end{array}$ \\
\hline 16 & $\begin{array}{l}\text { Koushki et al. } \\
(2005)\end{array}$ & Verbal instructions at site level & $\begin{array}{l}\text { Log notes confirmed, } \\
\text { variation log }\end{array}$ \\
\hline 17 & $\begin{array}{l}\text { Iyer and Jha } \\
(2005)\end{array}$ & $\begin{array}{l}\text { High scope of temporary works, } \\
\text { plant idling }\end{array}$ & $\begin{array}{l}\text { Efficiency ratio, waiting } \\
\text { time }\end{array}$ \\
\hline 18 & $\begin{array}{l}\text { Chester and } \\
\text { Hendrickson } \\
(2005)\end{array}$ & Labour inefficiency, plant idling & $\begin{array}{l}\text { Contract rate vs. actual rate, } \\
\text { productivity ratio }\end{array}$ \\
\hline 19 & $\begin{array}{l}\text { Cotton et al. } \\
\text { (2005) }\end{array}$ & Labour inefficiency & Productivity ratio \\
\hline 20 & $\begin{array}{l}\text { Yahya and } \\
\text { Boussabaine } \\
(2006)\end{array}$ & $\begin{array}{l}\text { Wastage of materials, labour, } \\
\text { omitted works, missing items in the } \\
\text { bill of quantities, }\end{array}$ & $\begin{array}{l}\text { Abortive work schedule } \\
\text { approved }\end{array}$ \\
\hline 21 & $\begin{array}{l}\text { Walsh et al. } \\
\text { (2006) }\end{array}$ & $\begin{array}{l}\text { Wrong method of resource handling, } \\
\text { change in sequence of site operations }\end{array}$ & $\begin{array}{l}\text { Cost performance index } \\
(\mathrm{CPI}), \text { schedule performance } \\
\text { index }\end{array}$ \\
\hline 22 & Dixon (2006) & additional functionalities & Return on investment \\
\hline 23 & Berman (2006) & Low productivity & Productivity ratio \\
\hline 24 & $\begin{array}{l}\text { Walsh et al. } \\
\text { (2006) }\end{array}$ & $\begin{array}{l}\text { Wrong methods of resources } \\
\text { handling }\end{array}$ & Amount of loss recovered \\
\hline 25 & $\begin{array}{l}\text { Yahya and } \\
\text { Boussabaine } \\
(2006)\end{array}$ & $\begin{array}{l}\text { Change in the sequence of work and } \\
\text { methods statement }\end{array}$ & Productivity ratio \\
\hline 26 & Owens (2007) & Additional works in small quantities & Mean absolute deviation \\
\hline 27 & Azhar et al. (2008) & $\begin{array}{l}\text { Unstable costs of the manufacturing } \\
\text { materials. }\end{array}$ & Cost target \\
\hline
\end{tabular}




\begin{tabular}{|c|c|c|c|}
\hline \# & Author & $\begin{array}{l}\text { Factors contributing scope creep } \\
\text { in road projects }\end{array}$ & KPI recommended \\
\hline 28 & $\begin{array}{l}\text { Ward and } \\
\text { Chapman (2008) }\end{array}$ & $\begin{array}{l}\text { Incremental change in the original } \\
\text { scope of the work and its time } \\
\text { impact }\end{array}$ & $\begin{array}{l}\text { Schedule performance index } \\
\text { (SPI), }\end{array}$ \\
\hline 29 & Pewdum (2009) & $\begin{array}{l}\text { Changes in source of supply of } \\
\text { materials }\end{array}$ & Number of claims settled \\
\hline 30 & $\begin{array}{l}\text { Shane et al. } \\
\text { (2009) }\end{array}$ & Idling of machinery & Cost limit \\
\hline 31 & Turk (2010) & $\begin{array}{l}\text { Ambiguous, vague scope fi work } \\
\text { reticence could be a precursor to } \\
\text { failure. }\end{array}$ & $\begin{array}{l}\text { Variation log, Reduced } \\
\text { preliminaries }\end{array}$ \\
\hline 32 & $\begin{array}{l}\text { Olawale and Sun } \\
(2010)\end{array}$ & Design changes from time to time & Variation log \\
\hline 33 & $\begin{array}{l}\text { Fang and } \mathrm{Ng} \\
(2011)\end{array}$ & Wastage in handling materials & $\begin{array}{l}\text { Approved Day Work } \\
\text { Schedule }\end{array}$ \\
\hline 34 & Jayalath (2011) & $\begin{array}{l}\text { Original contract scope increased } \\
\text { substantially, change in invert levels, } \\
\text { change in mix proportions, change in } \\
\text { intervals in joints, bases, thresholds } \\
\text { etc. }\end{array}$ & Schedule variance \\
\hline 35 & Jayalath (2011) & Changes in the method of execution & $\begin{array}{l}\text { Actual cost of works } \\
\text { performed }\end{array}$ \\
\hline 36 & $\begin{array}{l}\text { Wijekoon and } \\
\text { Attanayake (2011) }\end{array}$ & Changes in end user requirements & $\begin{array}{l}\text { Burn rate, variation log, } \\
\text { omitted work schedule, day } \\
\text { work schedule approved }\end{array}$ \\
\hline 37 & $\begin{array}{l}\text { Fang and } \mathrm{Ng} \\
(2011)\end{array}$ & $\begin{array}{l}\text { Wastage during heavy usage of raw } \\
\text { materials }\end{array}$ & Attendance fees settled \\
\hline 38 & Jayalath (2011) & $\begin{array}{l}\text { Deviation as to the methods of } \\
\text { execution as planned. Slight changes } \\
\text { allowed to the original project scope }\end{array}$ & $\begin{array}{l}\text { Work certified to date, } \\
\text { variation approved }\end{array}$ \\
\hline 39 & $\begin{array}{l}\text { Fang and } \mathrm{Ng} \\
(2011)\end{array}$ & Wastage, in the use of materials & Billing analysis \\
\hline 40 & Jayalath (2011) & Additional functionalities & Return on investment \\
\hline 41 & De Marco (2013) & $\begin{array}{l}\text { Little changes to the planned base } \\
\text { line, work scope and schedule }\end{array}$ & $\begin{array}{l}\text { Claimed vs. approved } \\
\text { (variations log) }\end{array}$ \\
\hline 42 & $\begin{array}{l}\text { Wijekoon and } \\
\text { Attanayake (2013) }\end{array}$ & $\begin{array}{l}\text { Low precision of the estimates, } \\
\text { inaccurate site investigation, }\end{array}$ & $\begin{array}{l}\text { Request for Information } \\
\text { (RFI) responded, schedule } \\
\text { for approved day work }\end{array}$ \\
\hline 43 & De Marco (2013) & $\begin{array}{l}\text { Changing the planned base line, } \\
\text { work scope and schedule. }\end{array}$ & Variations \\
\hline 44 & Shrestha (2014) & $\begin{array}{l}\text { Last minute adjustments to project } \\
\text { scope in order to rectify design } \\
\text { errors }\end{array}$ & $\begin{array}{l}\text { Budgeted cost of work } \\
\text { performed }\end{array}$ \\
\hline
\end{tabular}




\begin{tabular}{|c|c|c|c|}
\hline$\#$ & Author & $\begin{array}{c}\text { Factors contributing scope creep } \\
\text { in road projects }\end{array}$ & KPI recommended \\
\hline 45 & $\begin{array}{l}\text { Ghoddousi and } \\
\text { Poorafshar (2015) }\end{array}$ & $\begin{array}{l}\text { Plant idling, protracted delay in } \\
\text { approval process }\end{array}$ & $\begin{array}{l}\text { Number of variations } \\
\text { finalized, Disputed amount } \\
\text { vs. effective contract sum }\end{array}$ \\
\hline 46 & $\begin{array}{l}\text { Ghoddousi et al. } \\
\text { (2015) }\end{array}$ & Works done on, trial and error basis & $\begin{array}{l}\text { Productivity ratio, budgeted } \\
\text { cost of work completed }\end{array}$ \\
\hline 47 & Baek et al. (2016) & Incomplete drawings & $\begin{array}{l}\text { Potential change notices } \\
\text { (PCN) approved }\end{array}$ \\
\hline 48 & $\begin{array}{l}\text { Saidu and } \\
\text { Shakantu (2016) }\end{array}$ & $\begin{array}{l}\text { Large amount of materials wastage, } \\
\text { labour inefficiency, concomitant } \\
\text { changes in weather conditions, price } \\
\text { increases }\end{array}$ & $\begin{array}{l}\text { Standing time, budgeted cost } \\
\text { of work completed }\end{array}$ \\
\hline 49 & Kerzner (2017) & $\begin{array}{l}\text { Additional features and } \\
\text { functionalities }\end{array}$ & Cost variance \\
\hline 50 & Veen et al. (2017) & $\begin{array}{l}\text { Disruptive events due to a series of } \\
\text { individual changes }\end{array}$ & Cost per km \\
\hline
\end{tabular}

The foregoing literature review essentially carries out the detailed elaboration of various factors contributing scope creep and key performance indicators as a set of quantifiable measurements used to gauge the overall long-term performance in taming scope creep.

\section{RESEARCH METHODOLOGY}

The study used the mixed research method. Mixed research approach being a combination of qualitative and quantitative approaches can overcome the weakness of the two approaches (Creswell, 2014). It can also enhance the rationality and consistency of the results of a study while enabling strong recommendations (Amaratunga et al., 2002). The study commenced with a detailed literature survey to identify the factors affecting cost overrun and cost controlling techniques and used semi structured expert interviews to collect the qualitative data required. 15 experts were selected using purposive sampling. Interview findings were transcribed and analysed using NVivo 11 code-based content analysis software and used to develop the questionnaire to evaluate the effectiveness. Interview findings were used to identify the most prevalent scope creep management tools in road projects. The profile of 15 interviewees are basically senior quantity surveyors with more than 20 years' experience working in road projects (refer Table 2).

Questionnaire surveys allow collection of data from a large number of respondents in a standard manner without any influence from the researcher (Bhattacherjee, 2012; MacDonald and Headlam, 2008). 100 project level quantity surveyors working in different capacities and authorities were selected using purposive sampling (refer Table 2 ). Questionnaires were despatched via email and the response rate was $84 \%$.

The index of Mean Item Square (MIS) is the sum of the respondents' actual scores given by all the respondents as a proportion of the sum of all maximum possible scores on the 5-point scale. Weighting was assigned to each responses ranging from one to five for the responses of 'strongly disagree' to 'strongly agree' and 'Extremely unlikely' to 'Extremely likely', when expressed mathematically as given in Equation (01).

$$
M I S=(1 n 1+2 n 2+3 n 3+4 n 4+5 n 5) / \Sigma N
$$


Where; $\mathrm{n}_{1}=$ Number of respondents for extremely unlikely or strongly disagree; $\mathrm{n}_{2}=$ Number of respondents for unlikely of disagree; $n_{3}=$ Number of respondents for neutral; $\mathrm{n}_{4}=$ Number of respondents for likely or agree; $\mathrm{n}_{5}=$ Number of respondents for extremely likely or strongly agree; $\mathrm{N}=$ Total number of respondents. After mathematical computations, the criteria are then ranked in descending order of their MIS (from the highest to the lowest).

Table 2: Profile of the questionnaire survey respondents

\begin{tabular}{lccccc}
\hline \multicolumn{1}{c}{ Work experience } & & & & \\
No. of years & $\mathbf{1 1 - 1 5}$ & $\mathbf{1 6 - 2 0}$ & $\mathbf{2 1 - 2 5}$ & $\begin{array}{c}\text { Above } \\
\mathbf{2 5}\end{array}$ & Total \\
Designation & & & & & \\
\hline Senior QS & 22 & 14 & 5 & - & $\mathbf{4 1}$ \\
Chief QS & 4 & 11 & 17 & - & $\mathbf{3 2}$ \\
Cost Controller & - & - & 6 & - & $\mathbf{6}$ \\
Commercial Manager & & & 2 & - & $\mathbf{2}$ \\
Director & - & & 1 & 1 & $\mathbf{2}$ \\
Managing Director & & & & 1 & $\mathbf{1}$ \\
\hline & $\mathbf{2 6}$ & $\mathbf{2 5}$ & $\mathbf{2 1}$ & $\mathbf{2}$ & $\mathbf{8 4}$ \\
\hline
\end{tabular}

\section{RESEARCH FINDINGS AND DISCUSSION}

48 authors revealed a gamut of reasons behind scope creep in road projects. The causes such as plant idling, wastage, incremental changes to design are of frequent occurrence. In the meantime, these scholars recommended nearly 50 tools that are adoptable at site level; broadly classifiable into three mail groups based on the function it serves, namely technical, contractual and commercial. Expert interviewees were requested to map, the first ten scope creep management tools as identified in the order of prevalence, in the literature to the real-life project scenario, together with their measurement scales, which are literally the KPIs in managing costs in road projects. Some tools were identified as being used rarely, some as being used commonly, and others as being used quite frequently. The most prevalent KPIs in managing scope creep are basically variation orders, potential change notices and day work schedules. The perception of 84 respondents who participated in the questionnaire survey was derived in a 5-point Likert scale in order to gauge the effectiveness of KPI (refer Table 3).

The functions 'contract administration' 'earn value management and cost planning are the most effective functions in taming scope creep. The most effective tool of contract administration that gives the highest effectiveness in controlling scope creep is variation $\log$. Net change in scope and potential change notice schedules ranked the second and third in terms of effectiveness respectively. 'The highest number of KPIs, which is eleven have been identified for the cost management function, interim and final accounting. 'Mark-up eroded' and 'billing analysis' are the most significant KPIs among them. The KPI 'cost performance index' of the function 'earn value management 'obtained the highest MWR of 4.950 while the KPI 'return on investment' of the function; contingency management' obtained the lowest MWR of 2.013. A mapping of the first ten KPIs with the highest ever $(\overline{\mathrm{x}})$ values recorded in the questionnaire survey is presented in Table 3. 
Table 3: Effectiveness of KPIs of each cost management tool

\begin{tabular}{|c|c|c|c|c|c|}
\hline Pf & $\mathbf{R}$ & KPIs & $\overline{\mathbf{x}}$ & $\sigma \mathbf{X}$ & $\mathbf{R}$ \\
\hline \multirow[t]{9}{*}{$\begin{array}{l}\text { Contract } \\
\text { administration }\end{array}$} & \multirow[t]{9}{*}{1} & $\begin{array}{l}\text { Potential change notices (PCN) } \\
\text { approved }\end{array}$ & 4.568 & 0.856 & 1 \\
\hline & & $\begin{array}{l}\text { Net scope change (add and omit } \\
\text { schedule) }\end{array}$ & 3.965 & 0.829 & 2 \\
\hline & & Claimed vs. approved (variations log) & 3.850 & 0.783 & 3 \\
\hline & & Site logbook signed and confirmed & 3.560 & 0.820 & 4 \\
\hline & & $\begin{array}{l}\text { Request for information (RFI) } \\
\text { responded }\end{array}$ & 3.546 & 0.747 & 5 \\
\hline & & Approved day work schedule & 3.517 & 0.642 & 6 \\
\hline & & $\begin{array}{l}\text { Employer instruction (EI) the cost of } \\
\text { which is confirmed in principle }\end{array}$ & 3.442 & 0.531 & 7 \\
\hline & & Number of rework approved & 3.418 & 0.782 & 8 \\
\hline & & Abortive work schedule approved & 3.250 & 0.653 & 9 \\
\hline \multirow{6}{*}{$\begin{array}{l}\text { Earn value } \\
\text { management }\end{array}$} & \multirow[t]{6}{*}{2} & Cost performance index (CPI) & 4.750 & 0.782 & 1 \\
\hline & & Schedule performance index (SPI) & 4.243 & 0.834 & 2 \\
\hline & & Cost variance & 3.943 & 0.734 & 3 \\
\hline & & Schedule variance & 3.759 & & 4 \\
\hline & & Budgeted cost of the work performed & 3.724 & 0.750 & 5 \\
\hline & & Actual cost of works performed & 3.452 & 0.838 & 6 \\
\hline \multirow[t]{3}{*}{ Cost planning } & \multirow[t]{3}{*}{3} & Cost per km & 4.750 & 0.750 & 1 \\
\hline & & Cost limit & 4.439 & 0.820 & 2 \\
\hline & & Cost target & 4.129 & 0.765 & 3 \\
\hline \multirow{2}{*}{$\begin{array}{l}\text { Cash flow } \\
\text { forecasting }\end{array}$} & \multirow[t]{2}{*}{4} & Cash flow yield & 4.320 & 0.735 & 1 \\
\hline & & Cash flow margin & 4.200 & 0.851 & 2 \\
\hline \multirow{2}{*}{$\begin{array}{l}\text { Cost value } \\
\text { reconciliation }\end{array}$} & \multirow[t]{2}{*}{5} & Over measure deducted & 3.580 & 0.745 & 1 \\
\hline & & Under measure added & 4.002 & 0.869 & 2 \\
\hline \multirow{5}{*}{$\begin{array}{l}\text { Schedule } \\
\text { perform } \\
\text { variance }\end{array}$} & \multirow[t]{5}{*}{6} & Productivity ratio & 4.455 & 0.745 & 1 \\
\hline & & Efficiency ratio & 3.875 & 0.647 & 2 \\
\hline & & Waiting time & 3.900 & 0.836 & 3 \\
\hline & & Lead time & 3.745 & 0.829 & 4 \\
\hline & & Standing time & 3.410 & 0.683 & 5 \\
\hline \multirow{3}{*}{$\begin{array}{l}\text { Contingency } \\
\text { management }\end{array}$} & \multirow[t]{3}{*}{7} & Current ratio & 2.760 & 0.870 & 1 \\
\hline & & Burn rate & 3.875 & 0.740 & 2 \\
\hline & & Mean absolute deviation & 3.743 & 0.622 & 3 \\
\hline \multirow{4}{*}{$\begin{array}{l}\text { Interim/final } \\
\text { cost reporting }\end{array}$} & \multirow[t]{4}{*}{8} & Mark up eroded & 3.660 & 0.551 & 1 \\
\hline & & Billing analysis & 3.616 & 0.772 & 2 \\
\hline & & Contract rate vs. actual rate & 3.251 & 0.693 & 3 \\
\hline & & Variations & 3.875 & 0.781 & 4 \\
\hline
\end{tabular}




\begin{tabular}{llccc}
\hline \multicolumn{1}{c}{ Pf } & \multicolumn{1}{c}{ KPIs } & $\overline{\mathbf{x}}$ & $\boldsymbol{\sigma X}$ & $\mathbf{R}$ \\
\hline & Claims & 3.799 & 0.832 & 5 \\
& Timing of payments & 3.560 & 0.734 & 6 \\
& Number of variations finalized & 3.416 & & 7 \\
& Disputed amount vs. effective contract & 3.250 & 0.751 & 8 \\
& sum & & & \\
& Retention released & 3.100 & 0.830 & 9 \\
& Percentage of supplier account settled & 2.856 & 0.759 & 10 \\
& Attendance fees settled & 2.564 & 0.821 & 11 \\
& Amount of loss recovered & 3.650 & 0.826 & 12 \\
& Work certified to date & 3.620 & 0.829 & 13 \\
Value & Number of claims settled & 3.555 & 0.787 & 14 \\
engineering & Cost benefit ratio & 3.479 & 0.827 & 1 \\
& Advanced milestones & 3.200 & 0.744 & 2 \\
& Bonus for early completion & 3.120 & 0.652 & 3 \\
& Reduced preliminaries & 3.340 & 0.531 & 4 \\
& Enhanced functional value & 3.247 & 0.782 & 5 \\
& Reduced timing & 3.233 & 0.643 & 6 \\
\hline Life cycle & 10 & 3.082 & 0.782 & 1 \\
& Value for money & 2.930 & 0.734 & 2 \\
& Return on investment & 2.884 & 0.735 & 3 \\
\hline
\end{tabular}

$\mathrm{Pf}=$ Project function, $\sigma \mathrm{X}=$ Standard deviation; $\overline{\mathrm{x}}=$ Mean item score; $\mathrm{R}=$ Rank

\section{CONCLUSIONS AND RECOMMENDATIONS}

The results of the survey data analysis reveal that KPIs vary according to user's perspective. Further analysis displayed a substantial difference between scholars and practitioners' perceptions. However, ten indicators, the Mean Item Square for which was fallen within the 4 to 5 in the scale reported as being most useful. 'Contract management' is the most significant technique and its most important KPIs are Cost performance index (CPI), Cost per km and Potential change notices (PCN) approved. Experts concluded that most of the KPIs used are post contract lagging measures that do not provide the opening to make any adjustments. The most critical causes are client changes, unforeseen risk and unclear scope. The major effects are delays in project completion time and increasing cost of projects. Hence, it is imperative that a proper scope creep management tool is agreed upfront, constantly monitored and actions taken to avoid it changing in a way that exceed budget and the timescale. As an important contribution, a couple of prescriptions for mitigating the incidence of scope creep has been suggested. Further research could also be carried out to investigate in detail the cost impact of scope creep, in a quantifiable way.

\section{REFERENCES}

Aibinu, A. and Jagboro, G., 2002. The effects of construction delays on project delivery in Nigerian construction industry. International Journal of Project Management, 20, 593-599. 
Amaratunga, D., Baldry, D., Sarshar, M. and Newton, R., 2002. Quantitative and qualitative research in the built environment: application of "mixed" research approach. Work study.

Arditi, D., Akan, G.T. and Gurdamar, S., 1985. Cost overruns in public projects. International Journal of Project Management, 3(4), pp. 218-224.

Azhar, N., Farooqui, R.U. and Ahmed, S.M., 2008. Cost overrun factors in construction industry of Pakistan. In First International Conference on Construction in Developing Countries (ICCIDC-I), Advancing and Integrating Construction Education, Research \& Practice, pp. 499-508.

Baek, M., Mostaan, K. and Ashuri, B., 2016. Recommended practices for the cost control of highway project development. In Construction Research Congress, 2016, pp. 739-748.

Baloi, D. and Price, A.D., 2003. Modelling global risk factors affecting construction cost performance. International journal of project management, 21(4), pp. 261-269.

Basheka, B.C. and Tumutegyereize, M., 2011. Measuring the performance of contractors in government construction projects in developing countries: Uganda's context: Uganda Management Institute, Kampala, Uganda; Public Procurement and Disposal of Public Assets Authority, Uganda

Berman, E.M., 2006. Productivity in public and non-profit organizations: Strategies and techniques. Sage

Bhattacherjee, A., 2012. Social science research: Principles, methods, and practices. Textbooks collection. 3. [Online] Available from: http://scholarcommons.usf.edu/oa_textbooks/3

Chester, M. and Hendrickson, C., 2005. Cost impacts, scheduling impacts, and the claims process during construction. Journal of construction engineering and management, 131(1), pp.102-107.

Cotton, A.P., Sohail, M. and Scott, R.E., 2005. Towards improved labour standards for construction of minor works in low-income countries. Engineering, Construction and Architectural Management, 12(6), pp. 617-632.

Creswell, J.W., 2014. Research design: qualitative, quantitative, and mixed methods approaches. $4^{\text {th }}$ ed. United States of America: SAGE Publications, Inc.

De Marco, A., 2018. Project monitoring and control. In Project Management for Facility Constructions, pp. 123-145. Springer, Cham.

Dixon, M., 2006. Identity risks-scope creep, [Online] Available from: http://blogs.oracle.com/identity/entry/identity_risks_scope_creep [Accessed 10 April 2018].

Dlakwa, M.M. and Culpin, M.F., 1990. Reasons for overrun in public sector construction projects in Nigeria. International Journal of Project Management, 8(4), pp. 237-241.

Fang, Y. and Ng, S.T., 2011. Applying activity-based costing approach for construction logistics cost analysis. Construction Innovation, 11(3), pp. 259-281.

Ghoddousi, P., Poorafshar, O., Chileshe, N. and Hosseini, M.R., 2015. Labour productivity in Iranian construction projects. International Journal of Productivity and Performance Management, 64(6), pp. 811-830.

Gurlen, S., 2003. “Scope creep”, [Online] Available from: www.umsl.edu/sauterv/analysis/

Hanna, A.S. and Gunduz, M., 2004. Impact of change orders on small labor-intensive projects. Journal of Construction Engineering and Management, 130(5), pp. 726-733.

Hendrickson, C., 1998. Project management for construction. Carnegie Mellon University, PA 15213. [Online] Available at: http://pmbook.ce.cmu.edu/01_The_Owners'_Per spective.html [Accessed 10 April 2018].

Humaidi, N. and Said, N., 2011. The influence of project life cycle and key performance indicators in project management performance: Comparison between ICT and construction project: Faculty of Office Management \& Technology. The $2^{\text {nd }}$ International Conference on Construction and Project Management IPEDR, 15 (2011), IACSIT Press, Singapore.

Iyer, K.C. and Jha, K.N., 2005. Factors affecting cost performance: evidence from Indian construction projects. International journal of project management, 23(4), pp. 283-295.

Jayalath, C., 2011. Contractual dimensions in construction: A commentary in a nutshell, iUniverse: Indiana, USA.

Kerzner, H., 2017. Project management: a systems approach to planning, scheduling, and controlling. John Wiley \& Sons. 
Koushki, P.A. and Kartam, N., 2004. Impact of construction materials on project time and cost in Kuwait. Engineering, Construction and Architectural Management, 11(2), pp. 126-132.

Koushki, P.A., Al-Rashid, K. and Kartam, N., 2005. Delays and cost increases in the construction of private residential projects in Kuwait. Construction Management and Economics, 23(3), pp. 285-294.

Kumaraswamy, M., Mahesh, G., Mahalingam, A., Loganathan, S. and Kalidindi, S.N., 2017. Developing a clients' charter and construction project KPIs to direct and drive industry improvements, Built Environment Project and Asset Management, 7(3), pp. 253-270.

Larson, R. and Larson, E., 2009. Top five causes of scope creep and what to do about them. In $P M I ®$ Global Congress 2009 - North America, Orlando, FL. Newtown Square, PA: Project Management Institute.

MacDonald, S. and Headlam, N., 2008. Research methods handbook: Introductory guide to research methods for social research. Centre for Local Economic Strategies.

Malkanthi, S.N., Premalal, A.G.D. and Mudalige, R.K.P.C.B., 2017. Impact of cost control techniques on cost overruns in construction projects. Engineer, 50(4), pp. 53-60.

Narayanan, S., Kure, A.M., and Palaniappan S., 2019. Study on time and cost overruns in mega infrastructure projects in India, Journal of The Institution of Engineers (India): Series A, 100(1), pp.139145

Neely, A., Gregory, M. and Platts, K., 2005. Performance measurement system design: A literature review and research agenda. International Journal of Operations \& Production Management, 25(12), pp. 1228-1263.

Nivehithan, T., 2017. Review of current cost planning practices for building construction in Sri Lanka (BSc dissertation), Department of Building Economics, University of Moratuwa, Sri Lanka.

Olawale, Y.A. and Sun, M., 2010. Cost and time control of construction projects: inhibiting factors and mitigating measures in practice. Construction management and economics, 28(5), pp. 509-526.

Owens, J., 2007. Project cost control tools and techniques. [Online] Available from www.jasonowens.com/../projectcostcontroltoolsandtechniques.

Pewdum, W., Rujirayanyong, T. and Sooksatra, V., 2009. Forecasting final budget and duration of highway construction projects. Engineering, Construction and Architectural Management, 16(6), pp. 544-557.

Saidu, I. and Shakantu, W., 2016. The contributions of construction material waste to project cost overruns in Abuja, Nigeria. Acta Structilia, 23(1), pp. 99-113.

Shane, J.S., Molenaar, K.R., Anderson, S. and Schexnayder, C., 2009. Construction project cost escalation factors. Journal of Management in Engineering, 25(4), pp. 221-229.

Shrestha, P.P., Pradhananga, N. and Mani, N., 2014. Correlating the quantity and bid cost of unit price items for public road projects. KSCE Journal of Civil Engineering, 18(6), pp. 1590-1598

Smith, J. and Love, P.E., 2001. Adapting to clients' needs in construction - a dialogue. Facilities, 19 (1/2), pp. 71-79.

Sonuga, F., Aliboh, O. and Oloke, D., 2002. Particular barriers and issues associated with projects in a developing and emerging economy. Case study of some abandoned water and irrigation projects in Nigeria. International Journal of Project Management, 20(8), pp. 611-616.

Swan, W. and Kyng, E., 2004. An introduction to key performance indicators. Centre for construction innovation; Construction excellence, Northwest.

Thoor, S.R and Ogunlana, S.O., 2010. Beyond the 'iron triangle': Stakeholders' perception of key performance indicators (KPIs) for large-scale public sector development projects: International Journal of Project Management, 28 (2010), pp. 228-236

Turk, W., 2010. Scope creep horror. Defense AT\&L, 39(2), pp. 53-55.

Veen, A., Teicher, J. and Holland, P., 2017. Continuity or disruption? An assessment of changing work and employment in the Victorian construction industry. Labour \& Industry: A Journal of the Social and Economic Relations of Work, 27(3), pp. 193-212.

Walsh, K.D., Sawhney, A. and Vachris, M.A., 2006. Improving inter-spatial comparison of construction costs. Engineering, Construction and Architectural Management, 13(2), pp. 123-135.

Ward, S. and Chapman, C., 2008. Stakeholders and uncertainty management in projects. Construction Management and Economics, 26(6), pp. 563-577. 
Wijekoon, S.B. and Attanayake, A.M.C.T.K. (2012). Study on the cost overruns in road construction projects in Sri Lanka. International Conference on Sustainable Built Environment, Sri Lanka, Paper No 69. The Earls Regency Hotel, Kandy, 14-16 December 2012. Sri Lanka: University of Peradeniya.

Yahya, K. and Boussabaine, A.H., 2006. Eco-costing of construction waste. Management of environmental quality. An International Journal. 47, pp.777-780.

Zwikael, O., 2009. Critical planning processes in construction projects. Construction Innovation. 9(4), pp. 372-387. 